\title{
O KOLORACH MILOŚCI W JĘZYKU POLSKIM I NIEMIECKIM (ASPEKTY JĘZYKOWO-KULTUROWE)
}

\section{Wstęp}

Zagadnienia związane z miłością interesują niemalże każdego, ponieważ miłość zajmuje w życiu człowieka bardzo ważne miejsce. Słowo „miłość” ma wiele znaczeń. Jest na przykład miłość platoniczna, macierzyńska, synowska, erotyczna. Może być również miłość do muzyki, książek, gór, ojczyzny itp. W tym przykładowym wyliczeniu ujmuje się różne, odmienne formy miłości. Inna jest bowiem miłość będąca przywiązaniem do rzeczy, a inna gdy chodzi o osobę, o umiłowanie idei czy heroiczną wierność wyznawanym wartościom (Modarski 1996, s. 29).

W poniższych rozważaniach ograniczono się do jednego rodzaju miłości, tj. do miłości w tym sensie, w jakim pojawia się ona między dwoma osobami płci odmiennej. Jest ona rozumiana - jako głębokie uczucie, związane z pożądaniem, pociągiem fizycznym, namiętnością i zazdrością (por. Nowy słownik języka polskiego 2002, s. 461). Na przykładzie semantycznej analizy utrwalonych w języku polskim i niemieckim wyrażeń z elementem kolorystycznym, konotujących miłość i jej różne oblicza, postaram się uzyskać odpowiedź na następujące pytania: Jakimi kolorami może się mienić miłość w obydwu językach?, Jakie są fizjologiczne źródła symboliki barw miłości w polskiej i niemieckiej kulturze? Jakie są symboliczne treści kolorów miłości w obydwu językach? Czy sposób postrzegania miłości jest wspólny obu narodom, czy też różny?

Szukając językowych potwierdzeń związków miłości z kolorami oparto się na analizie źródeł leksykograficznych - wybranych słowników ogólnych języka polskiego i języka niemieckiego (tu Nowy stownik języka polskiego, Stownik frazeologiczny języka polskiego, Langenscheidts Großwörterbuch. Deutsch als Fremdsprache, Duden. Deutsches Universalwörterbuch, Duden. Redewendun-

* Dr Izabela Bawej, Uniwersytet Kazimierza Wielkiego, Instytut Neofilologii i Lingwistyki Stosowanej, ul. Grabowa 2, 85-601 Bydgoszcz. E-mail: iza_bawej@poczta.onet.pl 
gen) oraz opracowaniu o charakterze kulturowym (tu Słownik symboli), z których wyekscerpowano wyrażenia $\mathrm{z}$ elementem kolorystycznym, konotujące miłość.

\section{Zasadnicze aspekty miłości w życiu czlowieka}

Obserwacja tego, jak miłość jest postrzegana, pozwala zauważyć, że bywa ona najczęściej ujmowana w aspektach: psychologicznym, socjologicznym, fizjologicznym, etycznym, metafizycznym lub teologicznym (Maciołek 1996, s. 14).

Truizmem jest twierdzenie, że miłość jest złożonym stanem emocjonalnym. Miłość jest uczuciem, na które składają się trzy podstawowe stany. Na początku miłosnej relacji pojawia się stan nazywany namiętnością. Związany jest on z fizjologicznym pobudzeniem, stanowiącym zbiór silnych emocji zarówno pozytywnych - pożądania, zachwytu, radości, jak i negatywnych - niepokoju, tęsknoty. Namiętność to składnik miłości oparty głownie na pożądaniu (motywie) seksualnym. Następnie w bliskim związku powstaje intymność, która jest związana z bliskością psychiczną partnerów, polegająca na wzajemnym dzieleniu się przeżyciami, informacjami, na ujawnianiu przeżyć, na otwartości, odsłanianiu siebie, szacunku czy trosce. To składnik emocjonalny bliskiego związku. W dalszym etapie miłosnym może pojawić się zaangażowanie. Są to działania, myśli, uczucia ukierunkowane na przekształcanie relacji w trwały związek. Są one rezultatem świadomej decyzji, aby być ze sobą razem, wspólnie zamieszkać, zawrzeć związek małżeński. Zaangażowanie jest związane z wysiłkiem wkładanym w utrzymanie związku; zwiększa się powoli, a potem stabilizuje. Miłość w swojej dynamice zmienia się od namiętności do intymności, od intymności do zaangażowania. Stanowi ona zbiór bardzo złożonych doznań o charakterze seksualnym, emocjonalnym i poznawczym (Mandal 2011, s. 259-260).

Ludzie mogą doświadczać miłości na różne sposoby. Potocznie mówi się, że każda miłość jest inna, a każdy człowiek kocha „na swój sposób”. Jest miłość zmysłowa i romantyczna, polegająca na przeżywaniu miłości jako namiętności, na zafascynowaniu i na silnym pociągu fizycznym. Jest miłość przyjacielska - jest to rodzaj miłości opartej na intymności i na stopniowym, spokojnym budowaniu wzajemnej bliskości. Jest miłość jako gra, będąca rodzajem miłości opartej na zabawie, strategii i manipulacji, nastawionej na krótkotrwałe związki z wieloma partnerami. Jest miłość obsesyjna, zaborcza związana z całkowitym pochłonięciem kochaną osobą, pełna zazdrości i lęku przed odrzuceniem. Jest miłość praktyczna, polegająca na racjonalnym wyborze osoby partnera, który zaspokaja potrzeby praktyczne, jest odpowiedni dla wieku, pochodzenia czy religii. Jest miłość altruistyczna, oparta na dawaniu i przebaczaniu, na trosce o partnera i na poświęceniu (Mandal 2011, s. 261-262). 


\section{Barwy jako nośnik treści kulturowych w języku}

Kolorem posługują się ludzie we wszystkich kulturach, jednak poszczególne społeczeństwa używają go w sposób bardzo zróżnicowany - zarówno w zakresie palety barw, jak i przypisywanych jej znaczeń oraz celów jej zastosowania (Mocarska-Tycowa, Bielska-Krawczyk 2010, s. 9-10), ponieważ kolor jest też zjawiskiem społeczno-kulturowym. Każdy naród może nieco inaczej postrzegać świat, a wszystkie utrwalone w danym języku reakcje na barwy są wynikiem kultywowanych tradycji, nawyków myślowych, skojarzeń o charakterze politycznym, historycznym czy religijnym.

Człowiek nie potrafiłby żyć bez kolorów. Kolor jest nieodzownym elementem ludzkiego życia i opisu otaczającego go świata, „,co nie pozostaje bez wpływu na język, który jest przecież narzędziem służącym do opisywania rzeczywistości" (Szczęk 2010, s. 24). Istnieje bowiem ścisła zależność między życiem każdego społeczeństwa, a słownictwem, jakim się ono posługuje. Znaczenia poszczególnych słów, zwrotów czy wyrażeń często odzwierciedlają i przekazują określony sposób myślenia, charakterystyczny dla danej społeczności kulturowej, są one równocześnie kluczem do kultury danej wspólnoty językowej dla tych, którzy próbują ją poznać i zrozumieć (Wierzbicka 2007, s. 16, 21). Takich przykładów z zakresu codziennego życia, iż charakterystyczne właściwości każdego języka naturalnego są nierozerwalnie związane ze specyfiką kulturową wybranej społeczności językowej, mogą dostarczyć będące przedmiotem analizy określenia miłości z komponentem barwy. Jak podkreśla Wierzbicka (1991, s. 3), ,język nie odzwierciedla świata bezpośrednio; odzwierciedla ludzką interpretację świata [...]"1, ponieważ jest on instrumentem umożliwiającym doświadczanie, odbieranie, nazywanie i ocenianie otaczającej rzeczywistości. Każdy język odbija sposób życia danej społeczności. Jest ukształtowany jako forma myśli i ujmowania świata, dlatego wpływa on na sposób poznawania rzeczywistości pozajęzykowej, myślenia o niej i nazywania jej elementów przez swoich użytkowników. Jest on efektem pewnej postawy wobec otaczającego świata (por. Burszta 1998, s. 52; Grzegorczykowa 2007, s. 190).

Język pozostaje w określonej relacji do życia ludzi, którzy się nim posługują, do ich przyzwyczajeń, postaw intelektualnych. Z jednej strony jest rodzajem dokumentu, który ilustruje pozalingwistyczne typy ludzkich zachowań, z drugiej zaś jest nieodzownym elementem wszelkich ludzkich sposobów bycia (Malinowski 1987, s. 34, 36).

Wpływ na język, jakim posługuje się dana społeczność, mają społeczne i ekonomiczne warunki życia w jakich ona funkcjonuje, co znajduje swoje odbi-

\footnotetext{
${ }^{1}$ Słowa te wpisują się w koncepcję językowego obrazu świat, który jest charakterystyczny dla każdego języka (por. np.: Tokarski 1993; Grzegorczykowa 1999; Maćkiewicz 1999; Bartmiński 2004, 2009).
} 
cie w języku jako systemie symbolicznym i sposobie postrzegania rzeczywistości przez daną zbiorowość. W języku i jego specyficznych kategoriach zawarty jest myślowy i konstrukcyjny schemat danej kultury. Każda społeczność językowa posiada własne specyficzne klasy pojęciowe, za pomocą których porządkuje doświadczany świat. Życie ludzi jest zawsze kształtowane poprzez język, który ukierunkowuje ludzkie myślenie (Sapir 1978, s. 39, 48).

W tym miejscu warto przypomnieć za Anusiewiczem (1995, s. 3), że język jest podstawowym elementem kultury każdego narodu. W nim znajduje swoje odzwierciedlenie kultura danej społeczności:

[...] język jest jednym z najważniejszych składników kultury, zaś kultura jest zawarta w języku - jego systemie, tekstach, sposobach posługiwania się nimi [...]. [...] traktujemy język jako środek czy narzędzie służące wymianie informacji, ale również, a może przede wszystkim jako magazyn doświadczenia zbiorowego danej społeczności, odzwierciedlającego hierarchie wartości i systemy znaczeń oraz jako czynnik umożliwiający dostęp do świata tudzież poznanie go, w sposób z góry już określony (Anusiewicz 1995, s. 3).

Widzenie barwne jest nie tylko reakcją narządu wzroku i wyższych ośrodków mózgowych, lecz także procesem, w którym biorą udział wszystkie zmysły człowieka, i na który wpływa stan całego organizmu. Na przykład, gdy człowiek widzi barwę czarną, to chodzi nie tylko o odebranie pewnego bodźca, ale także o akt psychiczny, który może wpływać na stan psychofizyczny całego organizmu ludzkiego, co nie ma nic wspólnego ze zmysłem wzroku, np.: smutek, melancholia, uczucie przygnębienia, lęk, ale też stan pobudzenia nerwowego i zmysłowego, poczucie intymności czy przyspieszone tętno i szybszy oddech. Percepcja barw w świecie zewnętrznym pociąga za sobą całe działanie umysłowe i fizyczne odbiorcy, jego inteligencję, pamięć, światopogląd, doznania estetyczne i religijne. Reasumując, postrzeganie barw związane jest z symbolicznymi aspektami życia, dlatego ludzie przypisują barwom umowne właściwości zgodnie z przyjętymi konwencjami (por. Zausznica 1959, s. 457; Gross 1990, s. 57).

W odniesieniu do miłości nacechowana wartościująco jest strefa kolorystyki $\mathrm{oczu}^{2}$. W polskiej kulturze pozytywnie odbierane są oczy koloru zielonego, o których śpiewa m.in. Ewa Demarczyk: „Masz takie oczy zielone, zielone jak letni wiatr z zaczarowanych lasów i zaczarowanych pól”’3. Zielone oczy są w języku polskim źródłem wielu poetyckich porównań i metafor oraz motywem przewodnim nieskomplikowanej muzyki dyskotekowej. Ale np. Niemcy uważają, że oso-

2 Tematykę barw w odniesieniu do powierzchowności kobiet i mężczyzn podjęto także we wcześniejszej publikacji pt. Kolorowy świat w odbiorze Polaków i Niemców w szerszym kontekście językowo-kulturowym z roku 2018.

${ }^{3}$ Autorzy tekstu: Julian Kacper, Henryk Rostworowski; kompozytor: Zygmunt Konieczny; rok powstania 1967 (www.tekstowo.pl/piosenka.ewa-demarczyk, dostęp: 27.10.2018). 
by o zielonych oczach nie potrafią prawdziwie kochać, o czym świadczy niemieckie ludowe powiedzenie (http//www.gutefrage.net, dostęp: 27.10.2018):

Braune Augen sind gefährlich, aber in der Liebe ehrlich.

Blaue Augen Himmelssten, küssen und poussieren gern.

Grüne Augen, Froschnatur, von der Liebe keine Spur ${ }^{4}$.

Istotnym aspektem rozwoju symbolizmu barwy jest formalizacja jej znaczenia i wyrażanej przez nią treści, od prostego, naturalnego odczucia zrodzonego przez barwę do systemu symboli, w którym każda barwa ma sprecyzowaną treść. $\mathrm{Z}$ czasem symbolizm barw stał się niejako konwencją, w której żadne samowolne doznania emocjonalne nie występują. Należy jednak podkreślić, że zawsze będzie istniała grupa asocjacji indywidualnych, czyli takich, które odnoszą się do pojedynczej jednostki. Ktoś może asocjować barwę szarą ze swoją babką, która lubiła szare stroje, a niebieskie z oczami ukochanej osoby (por. Zausznica 1959, s. 458; por. także Gage 2008, s. 80-84).

Miłość, jaka istnieje pomiędzy mężczyzną a kobietą, może się mienić różnymi kolorami. Najczęściej mówi się, że kolorem miłości jest czerwień. Ale miłość może być także różowa, biała, czarna, żółta, niebieska, zielona, a nawet srebrna i złota $\mathrm{w}$ odniesieniu do jubileuszów par małżeńskich.

Kiedy ludzie zawierają związek małżeński, każdy kolejny rok bycia razem ma swoją specyficzną nazwę. Dwudziesta piąta rocznica ślubu nazywana jest w języku polskim srebrna, srebrnym weselem, srebrnymi godami, a w języku niemieckim Silberhochzeit. Srebro symbolizuje w tym kontekście wierność, szczęście i mądrość (Kopaliński 2015, s. 403). Pięćdziesiąta rocznica ślubu nazywana jest złota, złotym weselem, złotymi godami. Jej niemiecki ekwiwalent brzmi Goldhochzeit. Złoty jest tu symbolem miłości, mądrości, stałości, serca, szlachetności i szacunku (Kopaliński 2015, s. 502).

\subsection{Czerwony - rot}

W wielu kręgach kulturowych czerwień wiąże się z kolorem krwi, wojen, ognia i siły (por. Rzepińska 1966, s. 100; Gross 1990, s. 7-8).

Jednak najczęściej kolor czerwony kojarzy się z miłością, zmysłowością, sercem, szczęściem (Kopaliński 2015, s. 51) oraz życiem płciowym, a związek ten wywodzi się z fizjologii człowieka. Według psychologów czerwień działa stymulująco na system nerwowy człowieka. Czerwona barwa pobudza sympatyczny układ nerwowy, co powoduje podniesienie poziomu cukru we krwi, jej

\footnotetext{
${ }^{4}$ Oczy brazowe sa niebezpieczne, lecz w miłości stateczne.

Niebieskie oczy sa jak niebo, chętnie całuja i flirtuja.

Oczy zielone, natura żaby, gdziė̇ miłości ślady? (tłumaczenie własne).
} 
szybszy napływ do serca, wzrost ciśnienia oraz zwiększenie zdolności reakcji. Jeżeli człowiek patrzy na czerwień, równocześnie odczuwa jej działanie, ponieważ nieznacznie zostaje podrażniony nerw sympatyczny. Myśląc o czerwonym, wydaje się ludziom, że odczuwają ciepło tego koloru, jego energię, intensywność i piękno. Osobom, które są zakochane, robi się często gorąco, gdy myślą o ukochanej czy ukochanym, co jest następstwem podrażnienia systemu nerwowego. U niektórych miłość wyzwala poczucie siły, chęć działania i podejmowania się różnych wyzwań, na co wcześniej nie byli gotowi. Podrażnienie tego samego nerwu, gdy patrzy się na kolor czerwony, i gdy jest się zakochanym, stanowi podłoże symbolicznej treści koloru, dlatego rozpowszechnione jest twierdzenie, że miłość jest czerwona. W dawnych czasach istniał nawet zwyczaj łączenia pary kochających się ludzi poprzez wiązanie ich czerwonymi nićmi (Gross 1990, s. 58). Kolor czerwony jest także symbolem namiętności i podniecenia, np. często spotyka się czerwone światła przed domami publicznymi, a w niektórych lokalach zapala się czerwone lamy, aby wywołać szczególny nastrój wśród gości.

Naukowe potwierdzenie intuicyjnych sformułowań przyniósł wiek XX i badania psychologiczne nad oddziaływaniem barw na system wegetatywny człowieka, np. kolor czerwony powoduje zwiększenie zdolności reakcji, wydzielanie adrenaliny, rozszerzenie naczyń krwionośnych, zwiększenie przepływu krwi, co wpływa na barwę skóry i położonych pod nią tkanek (Tokarski 2004, s. 79). Czerwień powoduje przyspieszone bicie serca, wyzwala energię, wzmaga popęd, powoduje chęć zaspokojenie pożądania. Dlatego można powiedzieć, że czerwień jest nie tylko barwą namiętności, miłości fizycznej i duchowej, lecz także życia oraz płodności. Kolor czerwony jest symbolem ciała ludzkiego, energii, odwagi, wigoru i radości ${ }^{5}$.

W kulturze niemieckiej czerwień odnosi się do miłości fizycznej, ale często tej pozamałżeńskiej. Na przykład prostytutka $\mathrm{w}$ języku niemieckim nazywana jest Rotlicht-Dame ('dama-czerwone światło'). Widać tu nawiązanie do czerwonego światła, z którym najczęściej kojarzy się domy publiczne. W języku polskim motyw czerwieni w nazwie prostytutki nie jest językowo utrwalony. Ale wyraźny jest on w wyrażeniu dzielnica czerwonych latarni - Rotlichtbezirk (DDU), Rotlichtviertel $(L G D a F)$, w którym polska nazwa motywowana jest czerwoną barwą. Jest to teren, gdzie pracują osoby trudniące się prostytucją. Język niemiecki dysponuje także określeniem Rotlichtmilieu 'środowisko czerwonego światła' $(D D U)$, które konceptualizuje czerwony kolor latarni nad wejściem do domów publicznych i oznacza środowisko prostytutek. Warto w tym kontekście dodać, że dawniej w Niemczech prostytutki nazywane były także rote Mädchen ('czerwone dziewczyny') (Jia 2013, s. 65). Czerwony przyjął ujemne znaczenie w XIV wie-

\footnotetext{
${ }^{5}$ Na przykład w Chinach przyszła panna młoda ubierała się na czerwono, co miało oznaczać nowe życie, powodzenie i szczęście (Sun, Sun 1999, s. 98), a w Rzymie oblubienice nosiły czerwone welony, co było aluzją do płodności i miłości fizycznej (Kopaliński 2015, s. 51).
} 
ku: w 1398 roku wyszło w Kolonii zarządzenie, iż ulicznice mają nosić czerwone zasłony, zwane wówczas Rode Wilen. W średniowieczu w wielu dużych miastach niemieckich kobiety uprawiające prostytucję musiały nosić czerwone czapki nazywane rote Mützen lub rote Kappen (Gross 1990, s. 61).

Źródłem symboliki kulturowej czerwonego i rot są powiązania z krwią, która kojarzy się ludziom z życiem, aktywnością i emocjami. Dlatego połączenia z czerwonym i rot używane są w opisach zespołu reakcji fizjologicznych towarzyszących na przykład wczesnym stadiom zakochania. Wyrażenie czerwienić sie, czerwienieć (Nsjp) - rot werden ( $L G D a F)$ odnoszą się do stanów emocjonalnych, kiedy w człowieku wzbudza się namiętność i ogarnia go płomienne doznanie. Może też tu chodzić o zaczerwienienie jako symptom zawstydzenia. Warto dopowiedzieć, że w emocjach odzwierciedla się także prototyp czerwieni jako ognia: głębokiego uczucia sympatii lub zmysłowości. Emocje wiążą się z pulsowaniem krwi w ciele, z nagłym napływem krwi do twarzy lub organów płciowych. Czerwony kolor wywołuje pobudzenie, co bardzo dobrze widać także w świecie zwierząt. W okresie godowym wybrane części ciała samic przybierają intensywnie czerwony kolor, który ma być sygnałem zachęcającym samca do prokreacji.

Czerwień i rot kojarzą się w obu kulturach także z pięknem i kobiecością, np. w wyrażeniu czerwone usta - rote Lippen (DDU) chodzi o naturalnie czerwone wargi, niepomalowane na czerwono. Takie usta są oznaką zdrowia, energii fizycznej lub duchowej, urody, a w przypadku kobiety mogą wyrażać jej seksowność i wywoływać pożądanie u mężczyzn.

Czerwony i rot konotują zatem w obydwu językach piękno, kobiecość, zmysłowe pragnienie miłosne, pociąg fizyczny oraz prostytucję. Czerwony i rot są kolorami miłości fizycznej, również tej pozamałżeńskiej na przykład w domach publicznych i agencjach towarzyskich, uważanej przez wiele osób za grzeszną, nieprzyzwoitą i rozwiązłą.

\subsection{Różowy - rosig}

Różowy przypisywany jest miłości ujmowanej z perspektywy kobiecej - jako spokojnej erotyki sugerującej ciepło kobiecego ciała i jego urodę (Badyda 2008, s. 177). Różowy jest melanżem czerwieni i bieli, dominującą rolę pełni czerwony, a biały jako składnik różowego jest domieszką. Odcienie różowego mają związek z miłością i erotyzmem. W badaniach z zakresu psychologii użytkowej, tj. badaniach nad związkiem barw z ludzką osobowością, różowy jest określany jako „najbardziej kochający i kobiecy z kolorów”. Różowy konotuje miłość zmysłową, oczekiwanie lub pragnienie miłości oraz kobiecą zalotność (Tokarski 2004, s. 160,161$)$.

Johann Wolfgang Goethe pisał o barwie czerwonej: „Działanie tej barwy jest tak jedyne w swoim rodzaju jak jej istota. Wywołuje ona zarówno wrażenie powa- 
gi i dostojeństwa, jak i uroku i wdzięku, pierwsze - w swej ciemnej, zagęszczonej postaci, drugie - w stanie jasnym i rozcieńczonym. I w ten oto sposób godność wieku podeszłego i urok młodości stroić się mogą w szaty jednego koloru" (Goethe 1981, s. 303). Tokarski (2004, s. 160) uważa, że w cytacie tym nie pada słowo różowy, ale z opisu czerwieni ,jasnej i rozcieńczonej” można wywnioskować, że chodzi o barwę zbliżoną do różowego.

Językowych potwierdzeń związków koloru różowego z miłością nie ma jednak zbyt wiele. Kolory różowy i rosig konotują przede wszystkim kobiecą urodę, przywodząc na myśl jej piękno i delikatność:

różowe usta (Sfjp) - rosige Lippen, różowa cera (Sfjp) - ein rosiges Gesicht $(D D U)$, różowe policzki - rosige Wangen $(L G D a F)$, różowe paznokcie - rosa Fingernägel, różowa skóra - rosige Haut (DDU).

W zasobie słownikowym polszczyzny znajdują się leksemy: róż - środek kosmetyczny do malowania rumieńców (Nsjp), różować - barwić różem, malować rumieńce, różować policzki (Nsjp), różować się - różować sobie twarz, policzki (Nsjp). Można tu doszukać się związku konotacyjnego między urodą a środkiem czy zabiegiem kosmetycznym (por. Tokarski 2004, s. 160). Ekwiwalentem polskiego różu jest w języku niemieckim Rouge, który nakłada się na policzki lub usta - Rouge auflegen (DDU).

Przyjmuje się też, że różowy jest kolorem ludzi szczęśliwie zakochanych, gdyż patrzą oni na świat optymistycznie, są do niego pozytywnie nastawieni, co potwierdza występujące w obu językach określenie: patrzeć na świat przez różowe okulary $(N s j p)$ - durch die rosarote Brille sehen $(D R)$.

\subsection{Biały - weiß}

Z miłością, zwłaszcza tą niewinną, kojarzy się też biel. Kolor biały jest m.in. symbolem doskonałości, świętości, niewinności, czystości, małżeństwa oraz szczęścia (Kopaliński 2015, s. 17).

Biel jest symbolem początku i końca oraz ich zjednoczenia. Dlatego używana jest z okazji narodzin, chrztu, konfirmacji, wesela, inicjacji, a w niektórych społeczeństwach w przypadku śmierci. Biały do dzisiaj jest w Europie i w wielu krajach Ameryki najpopularniejszym kolorem stroju panny młodej. ${ }^{6}$. Biel w jej przypadku ma symbolizować niewinność i czystość (por. Bruns 2001, s. 205-207; Kopaliński 2015, s. 17): biała suknia (Ss) - weißes Kleid (DDU).

Zioło o nazwie podkolan biały (odmiana storczyka) było dawniej uznawane za kwiat miłości. W jego bulwach Słowianie dopatrywali się symboli związku małżeńskiego. Bulwy podkolanu białego przypominają bowiem dwa złączone ze

\footnotetext{
${ }^{6}$ W Japonii na przykład panna młoda podczas tradycyjnego ślubu ubrana jest w biały kostium o nazwie shiromuku (dosłownie 'biała niewinność'), w który dawniej ubierała się także osoba popełniająca honorowe samobójstwo, tzw. seppuku lub harakiri (Morita 2010, s. 159).
} 
sobą serca (Komorowska 2010, s. 74, 81). Także w języku niemieckim nazwa tej rośliny zawiera komponent bieli - weiße Waldhyazinthe.

Biały i weiß symbolizują zdrowie, np. zadbane i białe zęby - weiße Zähne, które są podstawą pięknego uśmiechu, a tym samym ładnego wyglądu. Osoby z olśniewającym uśmiechem są powszechnie postrzegane jako bardzo atrakcyjne, a nawet seksowne, zarówno wśród kobiet, jak i mężczyzn. W języku niemieckim istnieje też określenie schneeweiße Zähne ('śnieżnobiałe zęby'), których kolor motywowany jest bielą śniegu, w języku polskim mówi się 'olśniewająco białe zęby', jako nawiązanie do blasku i jasności.

Piękny może być też w niektórych kręgach kulturowych jasny kolor skóry, np.: biała skóra - weiße Haut, helle Haut, białe ręce - weiße Arme, weiße Hände. W dawnych czasach, np. w XIX wieku biała skóra była oznaką urody, elegancji, symbolem przynależności do wyższych sfer. Tylko prości ludzie byli opaleni i ogorzali. Białe ręce, biała skóra podkreślały wdzięk, czar, powab i piękno kobiety. Biała skóra świadczyła o jej delikatności, subtelności i elegancji w porównaniu z kobietą ciemnoskórą. Ponadto białe kobiety stanowiły i stanowią obiekt pożądania mężczyzn na przykład z krajów muzułmańskich. Dzisiaj w odniesieniu do mężczyzn biała skóra wartościowana jest w wielu kulturach negatywnie. Białe ciało mężczyzny jest postrzegane jako nieestetyczne, nieładne, świadczące o jego słabości w przeciwieństwie do mężczyzny opalonego czy o ciemniejszej karnacji, co jest szczególnie widoczne w świecie mody czy reklamy.

W języku polskim występują określenia osób z komponentem biały, które nie mają ekwiwalentów z bielą w języku niemieckim. Kolor biały w polskim językowym obrazie świata jest określeniem kobiet: biała płeć (Sfjp), biała niewolnica, czyli kobieta często wywożona za granicę, sprzedawana do domu publicznego i zmuszaną do prostytucji (por. Komorowska 2010, s. 100) oraz białogłowa, która jest przestarzałą nazwą kobiety zamężnej noszącej po ślubie biały zawój (białą podwijkę) na głowie.

Biel związana jest także z czystością moralną i niewinnością. Biel konotuje czystość w znaczeniu wstrzemięźliwości, stąd też w języku polskim występuje określenie biate matżeństwo, czyli związek, w którym małżonkowie nie utrzymują kontaktów seksualnych. W języku niemieckim mówi się na takie małżeństwo Josephsehe. Jest to nawiązanie do Józefa z Nazaretu, który poślubił Maryję Dziewicę. Rzadziej można spotkać określenia Engelsehe 'anielskie małżeństwo' lub weiße Ehe.

\subsection{Czarny - schwarz}

Kolorem namiętności w miłości jest czarny. Chociaż czerń jest najpoważniejszą barwą, kojarzy się np.: z ciemnością, czyli brakiem światła; oznacza śmierć cielesną i duchową - grzech i wieczne potępienie; symbolizuje 
złych ludzi, niebezpieczne choroby, brud i zaniedbanie (por. np. Gross 1990, s. 95-114), nie zawsze oznacza ona zło. W otaczającym człowieka świecie można też odnaleźć pozytywne wartości barwy. Czarny kolor jest bowiem także kolorem elegancji, np.: czarna wieczorowa suknia - schwarzes Abendkleid, czarny smoking - schwarzer Smoking, czarne buty na wysokim obcasie - schwarze Schuhe mit hohem Absatz; seksapilu, np.: czarne pończochy - schwarze Strümpfe, czarne podwiazki - schwarze Strumpfbänder, czarna bielizna - schwarze Unterwäche, mała czarna - das kleine Schwarze (por. Bawej 2011, s. 16-17).

Czarny nie musi być zatem brzydki. Wręcz przeciwnie. Czerń u kobiet może świadczyć o ich urodzie. Na przykład czarne oczy (Sfjp) - schwarze Augen (LGDaF) czy dlugie, czarne włosy (Sfjp) - lange, schwarze Haare (LGDaF) postrzegane są jako piękne, uwodzicielskie i zmysłowe. Mogą być symbolem namiętności, bo takie oczy i włosy mają kobiety o gorącym temperamencie, np. Włoszki. Taki sposób postrzegania czarnego i schwarz w odniesieniu do wyglądu zewnętrznego kobiety jest wspólny obu językom.

W okresie międzywojennym na Pomorzu panna młoda miała czarną suknię do ślubu, do której zakładała biały welon jako znak swojej niewinności. Czerń była postrzegana wtedy jako kolor wytworny, ale jednocześnie praktyczny i uniwersalny: czarną suknię można było ubrać na wszystkie uroczystości i rodzinne okazje, a na koniec życia zostać w niej pochowaną.

Warto w tym kontekście wspomnieć jeszcze o kominiarzu, który ma przynosić szczęście. Kiedyś kominiarz sięgał do pieców w odwiedzanych domach, brał sadzę z paleniska i smarował nią twarze obecnych w domu dziewcząt. Takie czernienie młodych kobiet miało w całej Europie to samo znaczenie: miało sprawić szybkie zamążpójście oraz zapewnić potomstwo (Gross 1990, s. 113). W języku niemieckim określenie kominiarz zawiera komponent barwy - der schwarze Mann, czego nie odnotowuje się w języku polskim.

Czarny konotuje w polskiej kulturze odmowę, co potwierdza idiom - czarna polewka (Sfjp), czyli zupa z krwi kury lub kaczki, podawana w dawnej Polsce starającemu się o pannę na znak odmowy. Język niemiecki posiada wprawdzie ekwiwalent czerniny z komponentem barwy Schwarzsauer, ale nie chodzi tu o odrzucenie propozycji małżeństwa. Jak podaje Komorowska (2010, s. 211), w języku polskim regionalnie występowało dawniej także wyrażenie zawierające określenie z kolorem szarym w połączeniu szara gęś jako podać szara gęś, czyli dać komuś kosza.

Czarny i schwarz konotują w języku polskim i niemieckim piękno i urodę kobiety. Ale pomiędzy nimi są też różnice, np. w języku niemieckim schwarz oznacza szczęście, a czarny w języku polskim odmowę. Trzeba jeszcze dopowiedzieć, że czarny kojarzy się z grzechem, ale na przykład z grzeszną miłością tylko czerwony. 


\section{5. Żólty - gelb}

Nie ma wielu językowych potwierdzeń związków koloru żółtego z miłością czy urodą. W średniowieczu w południowej Prowansji kolor żółty był symbolem rozkoszy (por. Komorowska 2010, s. 132; Kopaliński 2015, s. 512-513). W języku niemieckim określano ten stan nieco łagodniej: żółty oznaczał nagrodę miłości, a powiedzenie złamać żółte róże wyrażało osiągniecie szczytu szczęścia przez kochanków. To samo znaczenie miały również żółte kwiaty i w tym sensie je ofiarowywano, a zwłaszcza żółtą ostróżkę i pięciornik. Żółty szafran w mowie kwiatów oznacza „lubieżność” (Gross 1990, s. 131).

Goethe (1981, s. 295, 296) uważał, że barwa żółta znajduje się najbliżej światła. W postaci najbardziej czystej żółty ma zawsze cechy jasności, posiada pogodne, rozweselające i łagodne właściwości: „Jest to barwa znajdująca się najbliżej światła. (...) W postaci najbardziej czystej barwa żółta ma zawsze cechy jasności i posiada pogodne, rozweselające, łagodnie pobudzające właściwości. (...) I tak zgodnie z naszym doświadczeniem, iż barwa żółta sprawia wrażenie ciepła i przytulności” (Goethe 1981, s. 296).

Z czasem kolor żółty utracił swoją wartość i znaczenie. Jeśli barwa ta w swej czystej i jasnej postaci zostanie zabrudzona, zmieszana, pokryje nieczyste lub nieszlachetne powierzchnie, np. zwykłe sukno czy filc, zaczyna sprawiać nieprzyjemne wrażenie (Goethe 1981, s. 296). W ten sposób kolor godności i uznania zostaje zamieniony w barwę hańby, wstrętu i niesmaku. Dlatego żółty był też na przykład kolorem prostytutek i symbolizował nierząd ${ }^{7}$.

Żółty jest kolorem wytwarzanej przez wątrobę żółci, której przypisuje się związek z zatruwającymi organizm negatywnymi uczuciami złości i zazdrości. Kolor żółty już w czasach średniowiecznych związany był z uczuciem zawiści, zdrady oraz obłudy i nieszczerości (Komorowska 2010, s. 140). Dlatego żółty kojarzony jest z negatywnymi stanami emocjonalnymi, co widać wyraźnie, gdy mówi się ż̇ółknąć z zazdrości (Sfjp), gelb vor Neid werden (DR). Chociaż najczęściej zazdrości się komuś powodzenia czy sławy, można też być podejrzliwym wobec partnera i szaleć z zazdrości o niego. Zazdrość w związku może przybrać różne formy od ledwo zauważalnej do chorobliwej i zaborczej.

\subsection{Blau - niebieski}

Poświadczeń językowych z kolorem niebieskim odnośnie miłości nie ma, chociaż sam kolor może wyrażać to uczucie. Niebieski jest symbolem m.in.: czułości, niewinności, wierności, ale także niestałości i niewierności (Kopaliński 2015, s. 22).

\footnotetext{
${ }^{7}$ Na przykład dawniej we Francji drzwi do domu osoby skazanej za cudzołóstwo malowano na żółto. Żółty kolor był we Francji kolorem zdradzanych mężów. W Indiach obowiązywał zwyczaj, według którego narzeczona musiała przez sześć dni przed ślubem nosić stary żółty strój, aby odpędzić złe moce (por. Gross 1990, s. 132; Sun, Sun 1999, s. 99; Kopaliński 2015, s. 512-513).
} 
Miłość jest stanem, który wywołuje określony sposób zachowania się. Kategorią etyczną, która powinna towarzyszyć temu uczuciu jest wierność. Niebieski i blau powodują podrażnienie układu parasympatycznego, przez co doznaje się uspokojenia, wewnętrznej stabilności i harmonii. Osoby odczuwające tego rodzaju spokój, zapewniający wewnętrzną równowagę, uważane są za oddane i lojalne. Niebieski był początkowo symbolem wiecznej wierności. Rycerze nosili na cześć ukochanych dam niebieski strój. Gdy jednak uwielbianie damy trwało zbyt długo, nie było traktowane poważnie, stawało się uprzejmością, a z czasem obowiązkiem i pozorem, niebieski zaczął być odczuwany jako nudny. Zmęczeni zbyt długą adoracją jednej pani rycerze i szlachcice ubrani na niebiesko zaczęli starać się o względy innych dam. Dlatego przez rycerskie obyczaje miłosne niebieski stał się kolorem niewierności. W czasach inkwizycji niebieski był kolorem diabła, a kobietom w niebieskich spódnicach zarzucano, że zadawały się z szatanem i nazywano je czarownicami oraz kochankami czarta. W ludowych wierzeniach niebieskie kwiaty szybko tracą swoją barwę, bledną. Dlatego dawniej w Niemczech niebieskie kwiaty miały być symbolem niewierności. Na przykład w dorzeczu Mozeli bławatek nazywany także Blaurose ('niebieską różą') ma znaczenie niestałego serca (Gross 1990, s. 146-153). Obecnie w kulturze niemieckiej blau jest kolorem wierności, którą może symbolizować kwiat Vergissmeinnicht ('nie zapomnij mnie') - niezapominajka.

\subsection{Zielony - grün}

Zieleń jest symbolem m.in. przyrody, płodności, wiosny, odrodzenia, nieśmiertelności, miłości, płci żeńskiej, młodości i radości (Kopaliński 2015, s. 498). Warto dodać, że w średniowieczu zielony, obok żółtej barwy, był też znakiem prostytutek. $\mathrm{W}$ wielu niemieckich miastach prostytutki musiały nosić zółte chusty z wplecioną zieloną nicią lub spódnice z zieloną lamówką, aby kolor ich stroju był dla wszystkich jednoznaczny (Burg-assum.de - Die Prostitution im Mittelalter, DW: 3.11.2018).

W dawnych wierzeniach ludowych diabeł-zalotnik miał zielony strój, a protokoły z procesów czarownic opisują, że diabeł uprawiający nierząd z czarownicami miał być ubrany na zielono. W średniowieczu kolor zielony był symbolem rodzącej się miłości. Młody mężczyzna wkładający zielone ubranie dawał do zrozumienia, że jest zakochany lub poszukuje nowej miłości. W epoce „Wzniosłej miłości” zielony stanowił ważny symbol czystej, młodej miłości, ofiarowywanej „duchowej władczyni” (Gross 1990, s. 168-169).

Zieleń jest kolorem życia, dlatego tysiącom przedmiotów obrzędowych 'życie' nadaje zdobiąca je zieleń, np. wiązanka dla panny młodej (Gross 1990, s. 166).

Dzień ślubu w języku niemieckim określany jest jako die grüne Hochzeit $(D R)$ 'zielone wesele'. Zielony konotuje w tym kontekście radość i nadzieję na długi i szczęśliwy związek oraz rodzi uczucia pozytywne: pomyślność, powo- 
dzenie, zadowolenie. Niemcy określają lewą stronę ciała od serca 'zieloną stroną' - die grüne Seite $(D R)$. Dawniej dziewczyna, którą poproszono, aby przesunęła się na 'zieloną stronę' młodego mężczyzny, miała zdobyć jego serce. W niemieckiej kulturze zielony symbolizuje zatem stan zakochania, miłość, szczęście, radość i ślub (Gross 1990, s. 168).

W języku polskim mówi się stomiana wdowa (Sfjp), natomiast w niemieckiej kulturze - grüne Witwe 'zielona wdowa' $(D R)$. Jest to żartobliwe określenie żony, która mieszka poza miastem i czuje się samotna, ponieważ jej mąż jest często nieobecny w domu. Przytoczone określenie motywowane jest tylko w języku niemieckim zielonym kolorem.

Natomiast zielony opisuje w polskim obrazie świata etap ludzkiego życia - zielona miłość. Zieleń symbolizuje rodzącą się miłość, miłość niedojrzałą młodych i niedoświadczonych ludzi. W materiale języka niemieckiego nie odnotowano tego typu skojarzeń.

W tym kontekście należy podkreślić, iż konotacja miłości bardzo wyrazista w czerwieni, odnosi się do uczucia dojrzałego, w którym pierwiastki emocjonalne splatają się z doznaniami fizycznymi, a czasami te ostatnie dominują. Zieleń wiązana z miłością modyfikuje obraz uczucia, bo zielona miłość jest miłością się dopiero rodzącą, w której więcej jest radości z jej narodzin niż elementów erotyki (Tokarski 2004, s. 130).

\section{Podsumowanie}

W przytoczonych powyżej wyrażeniach z elementem kolorystycznym konotujących miłość odzwierciedlają się określone sposoby postrzegania miłości przez Polaków i Niemców. Są one głęboko zakorzenione w kulturze każdego narodu. Jak wynika z powyższego, miłość może się mienić różnymi kolorami od czerwonego poprzez różowy, biały, czarny, żółty, niebieski aż do zielonego.

Porównując konotacje semantyczne wybranych barw, można stwierdzić, że większość skojarzeń, jakie mają dwa narody z kolorami miłości, jest bardzo podobna w obu językach. Oprócz podobieństw istnieją także pewne różnice, odzwierciedlające nieco inne doświadczenia społeczno-kulturowe przedstawicieli obu kultur, np. w odniesieniu do czerwonego czy zielonego. W przywołanych określeniach nie ma również pełnej zgodności między językami w zakresie ilości ich językowych potwierdzeń: kolor czerwony (j. polski -3 przytoczenia, j. niemiecki - 10 przytoczeń), kolor zielony (j. polski - 1 przytoczenie, j. niemiecki - 3 przytoczenia). Nieznaczne różnice dotyczą także różowego (j. polski - 9 przytoczeń, j. niemiecki -7 przytoczeń), białego (j. polski -8 przytoczeń, j. niemiecki -6 przytoczeń), czarnego (j. polski - 10 przytoczeń, j. niemiecki -8 przytoczeń). Jedynie żółty ma po jednym przytoczeniu w obydwu językach. 
Z uwagi na ograniczone ramy niniejszego artykułu temat, który podjęto, nie został wyczerpany, a analizę wyrażeń określających miłość należałoby wzbogacić tekstami literackimi lub potocznymi, które mogłyby dać szerszy ogląd badanego problemu. Niniejszy artykuł ma być przyczynkiem do dalszych badań w tym zakresie.

\section{BIBLIOGRAFIA}

Anusiewicz J. (1995), Lingwistyka kulturowa. Zarys problematyki, Wrocław.

Badyda E. (2008), Świat barw - świat znaczeń w języku poezji Zbigniewa Herberta, Gdańsk.

Bartmiński J. (2004), Punkt widzenia, perspektywa, językowy obraz świata, [w:] J. Bartmiński (red.). Językowy obraz świata, Lublin, s. 103-120.

Bartmiński J. (2009), Językowe podstawy obrazu świata, Lublin.

Bawej I. (2011), Analiza porównawcza konotacji semantycznej czarnego koloru na materiale języka polskiego i języka niemieckiego, Linguistica Bidgostiana, t. VIII, s. 15-29.

Bawej J. (2018), Kolorowy świat w odbiorze Polaków i Niemców w szerszym kontekście językowo-kulturowym, Bydgoszcz.

Bruns M. (2001), Das Rätsel Farbe. Materie und Mythos, Stuttgart.

Burszta W. (1998), Antropologia kultury. Tematy, teorie, interpretacje, Poznań.

Gage J. (2008), Kolor i kultura. Teoria i znaczenie koloru od antyku do abstrakcji, przeł. Joanna Holzmann, Kraków.

Goethe J.W. (1981), Wybór pism estetycznych, wybrał, opracował i wstępem poprzedził Tadeusz Namowicz, Warszawa.

Gross R. (1990), Dlaczego czerwień jest barwa miłości, z niemieckiego przełożyła A. Porębska, Warszawa.

Grzegorczykowa R. (1999), Pojęcie językowego obrazu świata, [w:] J. Bartmiński (red.), Językowy obraz świata, Lublin, s. 39-46.

Grzegorczykowa R. (2007), Wstęp do językoznawstwa, Warszawa.

Jia L. (2013), Interkulturelle Kommunikation im Kontext der Kunstpädagogik. Der Farbgebrauch und die Bedeutung in China und Deutschland, Hamburg.

Komorowska E. (2010), Barwa w języku polskim i rosyjskim. Rozważania semantyczne, Szczecin.

Maciołek R. (1996), Źródła wspótczesnego rozumienia miłości, [w:] K. Kalka (red.), Do źródeł miłości (Filozoficzne i pedagogiczne problemy miłości), Warszawa, s. 14-28.

Maćkiewicz J. (1999), Co to jest językowy obraz świata, [w:] Etnolingwistyka, t. 11, s. 7-24.

Malinowski B. (1987), Ogrody koralowe i ich magia. Studium metod uprawy ziemi oraz obrzędów towarzyszacych rolnictwu na Wyspach Trobriando. Język magii i ogrodnictwa, [w:] Dzieła, t. 5, przełożyła B. Leś, red. A.K. Paluch, Warszawa.

Mandal E. (2011), Dynamika stanów emocjonalnych w bliskich zwiąkach, [w:] D. Doliński, W. Błaszczak (redakcja naukowa), Dynamika emocji. Teoria i praktyka, Warszawa, s. 256-282.

Mocarska-Tycowa Z., Bielska-Krawczyk J. (2010), Wprowadzenie, [w:] Z. Mocarska-Tycowa, J. Bielska-Krawczyk (red.), Kolor w kulturze, Toruń, s. 9-12.

Modarski R. (1996), O istocie miłości, [w:] K. Kalka (red.), Do źródeł miłości (Filozoficzne i pedagogiczne problemy miłości), Warszawa, s. 29-44.

Morita K. (2010), Nazwy barw w języku japońskim i polskim, [w:] A. Pajdziński, R. Tokarski (red.), Relatywizm w języku i kulturze, Lublin, s. 157-164.

Rzepińska M. (1966), Studia z teorii i historii koloru, Kraków.

Sapir E. (1978), Kultura, język, osobowość. Wybrane eseje, przełożyli B. Stanosz, R. Zimand, Warszawa. 
Sun D., Sun H. (1999), Kolory życia, przełożył D. Rossowski, Łódź.

Szczęk J. (2010), O postrzeganiu świata przez pryzmat barw $w$ języku niemieckim i polskim, [w:] Z. Mocarska-Tycowa, J. Bielska-Krawczyk (red.), Kolor w kulturze, Toruń, s. 23-36.

Tokarski R. (1993), Słownictwo jako interpretacja świata, [w:] J. Bartmiński (red.). Encyklopedia kultury polskiej XX wieku. T. 2. Współczesny język polski, Wrocław, s. 335-362.

Tokarski R. (2004), Semantyka barw we wspótczesnej polszczyźnie, Lublin.

Wierzbicka A. (1991), Uniwersalne pojęcia i ich konfiguracja w różnych kulturach, [w:] Etnolingwistyka, t. 4, s. 7-40.

Wierzbicka A. (2007), Słowa klucze. Różne języki - różne kultury, przełożyła I. Duraj-Nowosielska, Warszawa.

Zausznica A. (1959), Nauka o barwie, Warszawa.

\section{Źródla}

DDU - Duden. Deutsches Universalwörterbuch (2011), Dudenverlag: Mannheim, Zürich.

$D R$ - Duden. Redewendungen. Wörterbuch der deutschen Idiomatik (2001), Dudenverlag: Mannheim, Leipzig.

LGdaF - Langenscheidts Großwörterbuch Deutsch als Fremdsprache (1993), Langenscheidt: Berlin, München.

Nsjp - Nowy słownik języka polskiego (2002), red. E. Sobol, Warszawa.

Sfjp - Skorupka S. (1989), Stownik frazeologiczny języka polskiego, T. I-II, Warszawa.

Ss - Kopaliński W. (2015), Stownik symboli, Warszawa.

\section{Źródla internetowe:}

Burg-assum.de - Die Prostitution im Mittelalter (aus dem Sachbuch Alltag im Spätmittelalter von

Harry Kühnel [dostęp: 3.11.2018].

www.gutefrage.net [dostęp: 27.10.2018].

www.tekstowo.pl/piosenka.ewa-demarczyk [dostęp: 27.10.2018].

Izabela Bawej

\section{COLOURS OF LOVE IN POLISH AND GERMAN (LINGUISTICS-CULTURAL ASPECTS)}

(Summary)

The article describes six basic colour terms and their connotations concerning love on the basis of love between a woman and a man by prism of Poles and Germans. The analysis covers selected expressions with a colour element connoted a feeling of liking someone combined with sexual attraction to answer following questions: What colour does love have in Polish and German? What are physiological sources of the symbolism of love's colours in Polish and German culture? Is the perception of love similar or different in both languages?

Keywords: colour, love, connotation, culture 